by force, Victor Brailovsky, the host of the most well known of them, was sent to exile, a number of refusnik scientists recently lost their jobs. All of this indicates that the situation is approaching a critical stage which may become irreversibly tragic. As the most sinister sign we consider several recent statements of some officials that the problem of Jewish emigration from the Soviet Union no longer exists and that there are no more Soviet Jews wanting to emigrate (see for example the Baltimore Sun, 11 April).

Therefore we find it necessary to emphasize once again that emigration to Israel remains the only possible solution to our problems and that our decision to emigrate remains unshakeable.

So far the activity of Professor Legay has been limited to asking for necessary information only from the official Soviet Trade Union organization connected with the federation. In this way, a very serious human problem is likely to be reduced to a formal argument the outcome of which very much depends on the knowledge and arbitrariness of some bureaucrat or other. We are convinced that the problem can be properly understood only through direct contacts with those who are personally involved. We use this opportunity to invite Professor Legay or another representative of WFSW who would be able to consider the problem honestly and comprehensively to come here and to meet us and other refusnik scientists.

If WFSW wants to help us, it can do so by giving the problem the widest publicity. At this time it may seem that the problem is ours only, and, in a narrow sense, it is. But the solution is far-reaching as it may affect (and already does affect) the lives of many scientists all over the world, their interaction and their confidence in each other.

SOLOMON ALber JACOB ALPERT EITAN FINKELSTEIN GREGORY FREIMAN ALEXANDER IOFFE JOSEF IRLIN ARKADY LEBONOV ALEXANDER LeRNER NaUm MEIMAN MARK REITMAN

Moscow, Soviet Union

SIR - We are very concerned with the impression that may have been conveyed in the letter to Nature (11 February, p.452) from J.M. Legay, Secretary General of the World Federation of Scientific Workers.

In discussing an earlier letter written by a group of refusniks, he seems to have the impression that the number of scientists who have requested and been refused emigration visas is comparable to that of the number of signatories. He conveys this impression by comparing this letter with one he had received personally and suggests that "the situation has evolved since last year". The implication is that some of the signatories have emigrated. If this is the message, it is erroneous as well as dangerously misleading.

In a recent visit to the Soviet Union, two of our members ascertained that none of the signatories, either of the private or the published letter, has been granted an exit visa. Furthermore, our emissaries were assured that the problem is orders of magnitude greater than Mr Legay suggests. In Moscow alone, there are at least 50 Doctors of Science who are refusniks in addition to 300 Candidates of
Science, among an estimated total of 1,000 scientific workers in the same predicament. For the whole of the Soviet Union, with refusniks in Kiev, Leningrad, Kharkov and so on, a reasonable estimate would be a minimum of 2,000. An indication of the situation is a letter from 46 scientist refusniks which we hope will soon be published. These scientists, like their ten colleagues, to whom Mr Legay was replying (Nature 24 December 1981, p.688), have described the tragedy of their plight better than we could possibly do.

In the light of the fact that many refusnik scientists and their families have been subjected to arrests, long-term imprisonment, revocation of degrees (Nature 6 May, p.4), and other forms of harassment, it is remarkable that they continue to speak out forcefully.

ARTHUR Yelon AdI EISENBERG

Committee of Concerned Scientists, Quebec, Canada

\section{More on Ovid}

SIR - I dare say your correspondent $M$. Kamen-Kaye (Nature 8 July, p.114) would find much of interest on the early history of geology in Lyell's Principles of Geology (London, 1830). Ovid is quoted, as are other classical authors, and whatever one may think of Lyell's abilities as a historian, he was a damn good writer.

University of Oxford,

Gordon Chancellor

Department of Geology and Mineralogy, Oxford, UK

\section{Safe harbour}

SiR - Sr Alberto C. Taquini's letter regarding the Falkland/Malvinas Islands (Nature 10 June, p.430) omits the following salient facts. (1) Only through British help did the Argentine manage to throw off the Spanish yoke.

(2) After 1829 the Argentines used the islands as a convict settlement, the convicts revolted and made the Governor a prisoner.

(3) The intervention of the captain of HMS Cleo was due to this fact, and interference by the Governor and/or the convicts with an American whaling ship.

(4) Port Stanley was a port of refuge for sailing ships damaged in the passage round Cape Horn, ships of all nations. In fact the only port of refuge available for many miles. (5) It was clearly to the benefit of all that a stable administration was established there. (6) One can only imagine the Governor was thankful to be rescued and returned safely to his homeland as his country was either unable or unwilling to restore law and order.

JOHN R. BARTON

Winsford, Cheshire, UK

\section{Falklands alone?}

SIR - If F.W. Cousins would consult the mass of evidence assembled and sifted by Dr J. Goebel in The Struggle for the Falkland Islands (Yale University Press, 1927), he would be forced to agree that the account of the history given by Señor Taquini is broadly correct (Nature 10 June, p.450 and 1 July, p.8).

The early navigators' accounts are far too confused for any certainty about the first sighting, though the most likely candidate is a ship of Camargo's armada in 1540, (note the mention of foxes - Darwin's 'Falkland fox', Canis antarcticus?). But in any case discovery by itself has never been accepted as conferring sovereignty (did not Cook discover New

Caledonia?).

The British case rests on the technicality that the establishment of Fort Egmont on West Falkland in 1766 predated the transfer of de Bougainville's colony on East Falkland to the Spanish crown in 1767. The French could have held out for their prior rights, but in view of the close relationship between the Bourbon kingdoms of France and Spain they backed down. It seems that the abandonment of Port Egmont was in fulfilment of a promise by George III, and it would hardly be honest to pretend that because it was unwritten it was never given.

Of the events leading up to the British takeover of 1833 it must be said that Louis Vernet's colony was broken up in 1831 by an American corvette, for alleged piracy, that the last Argentine governor was murdered by the remaining settlers shortly after his arrival in 1832 and that the British in 1833 found a state of anarchy on the islands. Vernet accepted compensation of $£ 2,400$ for his lost colony. Still it must be admitted that in 1833 the British claim to West Falkland was weak and to East Falkland weaker.

The important question, though, is why we are still talking about the rights and wrongs of events that happened before living memory, that affected very few people and that decided the fate of a very small territory. The restraint of Argentinian governments before Peron was more fitting to the dignity of a great nation than the subsequent strident claims.

Whatever happened up till 1833 , circumstances now are wholly different. Half a dozen generations of British people have lived in the islands, which are now no more Argentinian than Normandy is English or Mexico Aztec. There can be no going back to 1832. However, it is not possible either to go back to 1 April 1982, now that a thousand people have died for the islands. Neither side is likely ever to accept the other's sovereignty. By elimination, the only solutions likely ever to be satisfactory are independence or permanent UN trusteeship. In view of the fact that it was the United Nations that introduced the notion of negotiable sovereignty in 1965 , only independence seems likely to be acceptable to the islanders. Needless to say, independence would have to be declared by the islanders, rather than granted by the British, in order to be recognized by Argentina.

The question arises, how could so small a community with so few resources afford independence? The population would in fact only have to be multiplied by a factor of four to be equal to that of Nauru or Tuvalu, and this would not seem improbable. But biologists must view with anxiety the economic development that might go with population increase, for the islands are a laboratory and museum of sub-antarctic flora and fauna. Could not the international scientific community help to provide the dowry of an independent Falklands by agreeing to locate there the headquarters of organizations concerned with Antarctic research and conservation? The provision of services rather than the exploitation of natural resources would be the most appropriate basis for the islands' economy.

Philip J. Stewart

Deparment of Forestry,

University of Oxford, UK 